\title{
A Qualitative Research on Municipalities' Social Responsibility Practices in Izmir City
}

\section{İzmir İlindeki Belediyelerin Sosyal Sorumluluk Çalışmaları ile İlgili Nitel Bir Araştırma}

\author{
Emel Kursunluoglu Yarimoglu, Yasar University, Turkey, emel.kursunluoglu@yasar.edu.tr \\ Fatma Hacioglu, Yasar University, Turkey, fatma.hacioglu@yasar.edu.tr \\ Selin Gencturk, Yasar University, Turkey, selin.gencturk@yasar.edu.tr \\ Yasemin Kamali Celik, Yasar University, Turkey, yasemin1310@yahoo.com \\ Can Sayginer, Yasar University, Turkey, cansayginer@gmail.com
}

\begin{abstract}
The purpose of this study was to analyze the social responsibility practices of municipalities in Izmir City. Since the main purpose was to analyze different social responsibility practices of municipalities; two municipalities from urban districts, Karabaglar and Bornova, and two municipalities from rural districts, Kemalpasa and Seferihisar, were selected for qualitative research by using maximum variation sampling technique. The aim was to represent the social responsibility practices of municipalities chosen, not to generalize the findings to all municipalities in Izmir City. The technique of semi-structured interviewing was used to gather profound information regarding municipalities' social responsibility practices. One municipal official from each municipality who works for managing social responsibility practices was chosen for the interview. While data obtained from the research was analyzing, direct quotations that reflect the interviewees' opinions were used. According to the findings; it was found that municipalities conducted social responsibility practices regarding social support, health, education, culture, environment, and animals. It was recommended to municipalities that they should improve their social responsibility practices in order to ensure social welfare. Only four municipalities of total thirty municipalities in Izmir City were included to the research. The other municipalities' social responsibility activities may be examined in further research within the scope of constituting a general social responsibility plan for Izmir City. This research contributes to the literature because it represents the social responsibility practices implemented by the municipalities in Izmir City.
\end{abstract}

\section{Keywords: Social Responsibility, Municipality ,Local Government,Interview, Turkey.}

Öz: Bu çalıșmanın amacı, İzmir ilindeki beledivelerin sosyal sorumluluk çalıșmalarını incelemektir. Ana amaç, belediyelerin farklı sosyal sorumluluk faaliyetlerini incelemek olduğu için; İzmir merkez ilçelerinden iki belediye, Karabağlar ve Bornova, ve diş ilçelerinden iki belediye, Kemalpaşa ve Seferihisar, maksimum çeşitlilik örnekleme tekniği ile nitel araştırma için seçilmiştir. Amaç; elde edilen bulguları İzmir'deki tüm belediyeler için genellemek değil, seçilen belediyelerin sosyal sorumluluk faaliyetlerini göstermektir. Belediyelerin sosyal sorumluluk çalışmaları ile ilgili detaylı bilgi toplamak için yar yapılandırılmış görü̧sme tekniği

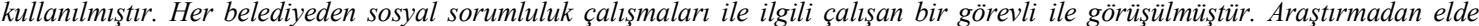
edilen veriler analiz edilir iken görüşülen kişilerin düşüncelerini yansıtan doğrudan alıntılar kullanılmıştır. Bulgulara göre; belediyelerin sosyal destek, sağllk, eğitim, kültür, çevre ve hayvanlar ile ilgili sosyal sorumluluk faaliyetleri düzenledikleri ortaya çıkmıştır. Belediyelere sosyal refahın sağlanması için sosyal sorumluluk faaliyetlerini gelișstirmeleri tavsiye edilmiştir. Araştırmaya İzmir'in otuz belediyesinden sadece dört tanesi dahil edilmiştir. İzmir ili için genel bir sosyal sorumluluk planı oluşturulması kapsaminda, diğer belediyelerin sosyal sorumluluk faaliyetleri gelecek araștırmalarda incelenebilir. Bu araștırma, İzmir ilindeki belediyeler tarafindan yürütülmüss olan sosyal sorumluluk çalışmalarını gösterdiği için literatüre katkıda bulunmaktadır.

Anahtar Kelimeler: Sosyal Sorumluluk, Belediye, Yerel Yönetim, Görüsme, Türkiye.

\section{Introduction}

Local governments were separated into three parts such as special provincial administrations, municipalities, and villages (The 1982 Constitution of the Republic of Turkey, Article 127). Special provincial administrations and villages are excluded in the subject of this study, but municipalities are included. Municipality is a public legal entity with administrative and financial autonomy established to meet the common needs of the inhabitants and have mandatory and discretionary duties (Municipality Law No. 5393, 2005). Municipalities have performed different social responsibility activities besides their mandatory and discretionary duties mostly related to environment, culture, education, and health. Besides the mandatory and discretionary duties of municipalities, social municipality keeps the municipalities responsible of the solutions of the social problems. Social responsibility activities may be more philanthropic in municipalities since their main aim is not being profitable and also their duties are nearly same with the nature of social responsibility activities. As it is too difficult for central governments to manage social problems, which are specific to the region or city, municipalities as part of local governments are seen as the local actor and decision maker for social problems. Rani and Hooda (2013) 
emphasized that the aim of the governmental social responsibility activities is to build the well-formed integrity between business and society.

In CSR literature, the benefits of CSR practices on companies were mostly analyzed, and many studies have focused on CSR activities' effects on companies from business perspective (Weber, 2008; Heal, 2005; Frynas, 2005; Sen et al., 2006; Du et al., 2010). Mostly social responsibility studies have analyzed the social responsibility activities of private companies such as banks (Narwal, 2007; Khan et al., 2009; Poolthong and Mandhachitara, 2009; Perez and del Bosque, 2012), oil companies (Frynas, 2005; Eweje, 2007), service providers such as Turkcell (Vural and Oksuz, 2009; Pasamehmetoglu, 2014; Ozdora-Aksak, 2015), food and beverage companies such as Starbucks (Argenti, 2004; Kolk, 2005; Maloni and Brown, 2006), and fast food companies such as McDonalds (Schröder and McEachern, 2005; Maloni and Brown, 2006; Valax, 2012). On the contrary of those studies, this study focused on analyzing the social responsibility practices of municipalities as one of the types of local governments.

This study focused on the social responsibility practices of municipalities and aimed to analyze municipalities' social responsibility practices in Izmir City. Firstly, local governments and municipalities were explained. Secondly, social responsibility practices and the practices of municipalities were shown. Then, the research was conducted to represent the findings regarding social responsibility practices of different municipalities in Izmir City. As a first stage of the research, a preliminary study was conducted through telephone interviewing and the websites of municipalities were scanned in order to understand the scope of municipalities. In the main part of the research, one municipal official from each municipality was interviewed. Insights from findings and the results were shown lastly.

\section{Local Governments \& Municipalities}

Local governments are defined in the 1982 Constitution as "public corporate bodies established to meet the common local needs of the inhabitants of provinces, municipal districts and villages, whose principles of constitution and decision-making organs elected by the electorate are determined by law" (The 1982 Constitution of the Republic of Turkey, Article 127). Toprak (2013b) said that local governments have both roles in democratic life and also functions to serve public services to the public, and they are the first step of inhabitants' participation in administration. Local governments in Turkey gained importance after the enactment of 1982 Constitution parallel with the changes in public administration paradigm in the world. The changing paradigm in public administration foresees the shrinking of the state although citizens' expectations from the state are increasing. Although central government can drawback from some areas, it doesn't have a chance of abstaining from the responsibility of serving public service to citizens. At this point, local governments supervised by central government and have legal personality are separated units elected by public votes occur as a solution (Gunal, 2013).

UNDP (2010) defines local governments as "formal institutions, mandated to deliver a variety of public goods and services at the local level. As local level service delivery units, local governments are largely predicated on the principle of subsidiarity, which stipulates that government functions should be assigned to the lowest level of government that is capable of efficiently undertaking this function". On the other hand, it can be said that Europe evaluates local governments within the frame of decentralization. According to decentralization theory "each public service should be provided by the jurisdiction having control over the minimum geographic area that would internalize benefits and costs of such provision" (Oates, 1972). In that way local governments can be closer to the people and may understand the problems of local residents. This can also provide a better and responsive local decision making system and elimination of unnecessary layers of jurisdiction (Shah and Shah, 2006).

Local governments were separated into three parts such as special provincial administrations, municipalities, and villages. Especially, there are important tasks of special provincial administrations and municipalities in the areas of social services and social aids (Cicek, 2010: 40). Special provincial administrations, municipalities, and villages are three types of local governments in Turkey. It will be beneficial to understand different types of local governments in terms of understanding the specific roles of municipalities. Special provincial administrations were defined as "a public entity having administrative and financial autonomy which is established to meet the common local needs of the people in the province and whose decision-making body is elected by voters" by the Law on Special Provincial Administration in 2005 (No. 5302, Article 3). Another type of local government is villages. They are founded in areas with low population and generally situated around rural establishments.

Municipalities are another part of local governments, which actually become focal point in this study. They were defined as "a corporation established in the statute of public legal entity having powers of self-government (autonomous) both administratively and financially, to meet the local and common requirements of the county inhabitants and the decision maker of which is elected by the electors" by the 
Municipality Law in 2005 (No. 5393, Article 3). Local governments are also classified under two different branches in application depending upon political and economic relations. In the first model which is called agency model, local governments are not independent and they act as a "part" of central government. In the second model, local governments act as a "partner" to central government and they become more independent (Gunal, 2013). However, the first model of local governments was generally observed in Turkey, which acts as an agency of central government.

The number of municipalities before 1923 was 421 whereas it was 3.225 in 2008 . There have been a huge increasing in the number of municipalities between these years. The number of municipalities in 2008 was reduced to 2.950 in 2010 within the Law No. 5393 and No. 5747, and until the end of 2013 the number of municipalities was 2.950. In 2013, reorganization activities were seen regarding the local governments. In 2013, most of the municipalities' legal personalities were eliminated by the Law No. 6360 and the number of municipalities decreased to 1.396 sharply in 2014 (Mahalli İdareler Genel Müdürlüğü, 2014: 7).

Table 1. The Number of Municipalities according to its types in 2013 and 2014

\begin{tabular}{|l|r|r|r|r|r|r|}
\hline & $\begin{array}{l}\text { Metropolitan } \\
\text { Municipality }\end{array}$ & $\begin{array}{l}\text { Metropolitan District } \\
\text { Municipality }\end{array}$ & $\begin{array}{l}\text { Provincial } \\
\text { Municipality }\end{array}$ & $\begin{array}{l}\text { District } \\
\text { Municipality }\end{array}$ & $\begin{array}{l}\text { Town } \\
\text { Municipality }\end{array}$ & Total \\
\hline 2013 & 16 & 143 & 65 & 749 & 1.977 & 2.950 \\
\hline $2014 *$ & 30 & 519 & 51 & 400 & 396 & 1.396 \\
\hline \multicolumn{7}{|c|}{ The data of 2014 has shown the number of municipalities after the Law No. 6360. } \\
Source: Mahalli İdareler Genel Müdürlüğ̈̈, 2014: 11.
\end{tabular}

Municipality is a public legal entity with administrative and financial autonomy established to meet the common needs of the inhabitants, whose reference law is the Municipality Law No. 5393 dated 2005. The Turkish Government made the Municipality Law in 2005 which stated about the duties and the functions of municipalities without any special emphasis on social responsibility duties of municipalities. According to this law, municipalities have mandatory and discretionary duties as shown below (Municipality Law, 2005; General Directorate of Local Authorities, 2011: 44-45).

Mandatory Duties:

- Urban infrastructure: land development, water, sewage and transportation,

- Geographical and urban information systems,

- Environment, environmental health, sanitation, and solid waste,

- Municipal police, fire-fighting, emergency aid, rescue and ambulance services,

- Urban traffic, funerals and cemeteries, forestation, parks and green areas,

- Housing,

- Culture and art, tourism and promotion, youth and sports, social services and social aid, weddings, vocational and skill-building training,

- Economic and commercial development,

- Establishing shelters for women and children (only in metropolitan municipalities and municipalities with population over 50.000).

Discretionary Duties:

- Undertake the construction, repair and maintenance of the state schools,

- Open and operate all health-care facilities,

- Preserve the cultural, natural, and historical assets,

- Provide supplies to students and amateur sport clubs,

- Perform food banking.

It was emphasized in the literature that "The instruments necessary for democratic Municipalities to be able to implement 'governance practices' are worth examining first in terms of the Municipality Law No. 5393 dated 2005 as well as the Metropolitan Municipality Law No. 5216 dated 2004" (Karaman, 2010: 327). Metropolitan Municipality Law No. 5216 enacted in 2004 as the leading law for determining the duties of municipalities. Law No. 5216 Article 7, Article 8, Article 9 also show the duties and responsibilities of metropolitan, district, and first-tier municipalities (Metropolitan Municipality Law, 2004; Toprak, 2013a: 14-15).

\section{Social Responsibility \& Municipalities}

Social responsibility has been largely discussed all over the world. Along with the increasing importance of social responsibility implementations, scholars and organizations have especially started to pay attention to this term to reach high level social advancements. However, both in the business and 
academic world, there is uncertainty about the social responsibility definitions (Dahlsrud, 2008; Crowther and Aras, 2009).

The various definitions of social responsibility are shown as follows: Bowen's (1953) focused on social responsibility is an important truth that guides business in the future. It can also be defined as an economic and technical interest (Davis, 1960), economic obligations, legal obligations, and responsibility to society (Manne and Wallich, 1972). Friedman (1970) emphasized that social responsibility activities are done just for profit whereas Chaudhary (2009) emphasized that social responsibility activities show that what and how companies go beyond profit. Kotler and Lee (2005) defined social responsibility as "... a commitment to improve community well-being through discretionary business practices and contributions of corporate resources".

Carroll and Buchholtz's (2008: 36) definition for social responsibility is about the obligations such as economic, legal, ethical, and discretionary (philanthropic) expectations towards society. Carroll (1979)'s four-part definition was used in this definition which categorized the types of social responsibility such as economic, legal, ethical, and philanthropic (voluntary/discretionary). Philanthropic social responsibility was defined as being a good corporate citizen and improving the quality of community's life; ethical responsibilities included being ethical; legal responsibilities were related to obeying the law; and economic responsibilities contained being profitable which is already the main aim of organizations. Carroll (1991) defined philanthropic domain of social responsibility as "corporate citizenship".

The definitions above showed that the main purpose of social responsibility activities is to contribute corporate resources and sustainable development, to improve community, to protect environment. These aims can be accepted by both private and public companies. However, in private sector it can be seen as more profit-based. On the contrary, in public sector, the implementations of social responsibility can be seen as more philanthropic. The main difference between private and public sector is that social responsibility activities can be more philanthropic in municipalities since their main aim is not being profitable and also their duties are nearly same with the nature of social responsibility activities.

Rani and Hooda (2013) emphasized that the aim of the governmental social responsibility activities is to build the well-formed integrity between business and society. Government plays a key role in controlling social responsibility activities among owners, employees, customers, and suppliers for sustainable achievements in society. They emphasized that social responsibility concept has been established for corporations as a framework for protecting community engagement, global warming, water management, managing the use of natural resources, and human rights. Within this context, municipalities as part of local governments carry an important role in terms of realizing social responsibility activities as they are closer to society when we compare local governments to central governments. As they are closer to society, municipalities have more chance and ability in order to understand the needs of people. Specific place of municipalities in Turkish local government system makes social responsibility activities inevitable. Though Turkish government has enacted the Municipality Law which only stated about the duties and the functions of municipalities without any special emphasis on social responsibility duties of municipalities (Municipality Law No. 5393, 2005). Both mandatory and discretionary responsibilities and duties of municipalities as defined in the law actually engages with the concept of social responsibility. Importance of municipalities among local governments are increasing each day parallel with the developments in Europe and the world. Especially after the recession in 2009, European local governments are seen as "the key actors in responding to climate change and rising energy prices. Making municipal assets more energy efficient, increasing the use of renewable energy, reforming transportation, increasing the capacity of storm water drainage are all key tasks for local government" (Davey, 2011: 39). At that point, it is also seen that municipalities in Turkey have also awareness about renewable energy, energy efficiency, and climate change.

Municipalities have performed different social responsibility activities besides their mandatory and discretionary duties mostly related to environment, culture, education, and health. As it is too difficult for central governments to manage social problems, which are specific to the region or city, municipalities as part of local governments are seen as the local actor and decision maker for social problems. At that point, municipalities begin to engage in social responsibility activities, which is coined as "social municipality management" (Cicek, 2010).

Social responsibility activities of municipalities are evaluated under social municipality management which is a model that gives social control mechanism to local governance to plan and regulate social affairs such as protecting environment and educating public (Akdogan, 2002). Besides the mandatory and discretionary duties of municipalities, social municipality keeps the municipalities responsible of the solutions of the social problems.

Es (2007) classified the social responsibility duties of municipalities into three topics: 
1) Local social and cultural services: Home care, daily care, building sheltering and health support centers, services related to the elders and disabled people. 2) Local economic development: Developing training programs to provide qualified employee. 3) Other service areas: Medical support centers, preventing domestic violence, entertainment and cultural activities, preventing of crime, security of society, aids such as free books and uniforms, free lunch for students, and the restoration of disabled people' apartments, lightening of the streets, transportation, and consultancy centers for giving information to the public about residential, health, birth control, prenatal period, job placement, and legal situations.

In Turkey, social municipality projects generally focused on cultural projects, disadvantaged people, youth centers, education, and housing. Some examples from the other municipalities of Turkey can be shown below (Ucakturk et al., 2009):

- Meram Municipality (one of the municipality of Konya City) has opened Children Shelters for the children who need protection, and has conducted the house cleaning of elders and meeting the needs of elders.

- Altindag Municipality (one of the municipality of Ankara City) has opened Dogantepe Shelter Houses for elders who are inadequate financially, and provided living conditions in these houses either alone or together with his wife in the apartment of 45 meters square. Also Altindag Municipality opened Guest Houses for the ill people and their relatives who came from out of Ankara.

- Izmir Metropolitan Municipality organized a city tour project for women who live in the districts which are far away from the city center, 4,700 women have participated in these tours since 2006, and they had the opportunity to recognize their city better. Also Izmir Metropolitan Municipality organized Welcome Newborn Baby project and delivered diapers for 15 days to the families of newborn babies.

- Konya Metropolitan Municipality developed the Social Database Center from the citizens' social data and determined the social situation of 180,990 families. Konya Metropolitan Municipality also developed Compassion Project and delivered breads to 200 families every day from their neighborhood groceries. Konya Metropolitan Municipality improved Homecare Project and serviced 259 families who are disabled, elders, sick, and in need of taking care. Konya Metropolitan Municipality supplied water with $50 \%$ discount to martyr and veteran families. Disabled people also buy water with $50 \%$ discount and use public transportation for free.

- Fethiye Municipality offered Women Guest House, Nursing Home, and Rehabilitation Center. Also Fethiye Municipality gave free books to the students who will take the university entrance exam.

Yuksel et al. (2006) mentioned about social responsibility and local governments in Tokat. They interviewed with the top level managers to measure the awareness of municipality about social responsibility and found out that there are some issues on "two way public relations" to contact with local settlers, but there are an effective attempts such as supporting internal education, sharing not only positive results but also negative results to the local settlers, creating policy done by obtaining support from nongovernmental organizations, having tendency to support non-governmental organizations and being sensible to social responsibility.

Gullupunar (2010) examined the social responsibility implementations of Konya Metropolitan Municipality which conducted courses for acquiring a profession, women housing, homeless housing, and translating Mesnevi's book into almost 27 languages. It was suggested that much projects are required for health, education, culture, and providing the mutual interaction between municipality and citizens. European Commission (2013) addressed that the capacity of small municipalities in Turkey is weak to deliver public services. As a result, municipalities and partnerships started to discuss for providing a high level support of individuals for religion, technology, and social. In this paper, small municipalities from Izmir were searched in terms of their social responsibility activities' focus points.

\section{Aim of the Research}

In CSR literature, the benefits of CSR practices on companies were mostly analyzed, and many studies have focused on CSR activities' effects on companies from business perspective (Weber, 2008; Heal, 2005; Frynas, 2005; Sen et al., 2006; Du et al., 2010). Mostly social responsibility studies have analyzed the social responsibility activities of private companies such as banks (Narwal, 2007; Khan et al., 2009; Poolthong and Mandhachitara, 2009; Perez and del Bosque, 2012), oil companies (Frynas, 2005; Eweje, 2007), service providers such as Turkcell (Vural and Oksuz, 2009; Pasamehmetoglu, 2014; OzdoraAksak, 2015), food and beverage companies such as Starbucks (Argenti, 2004; Kolk, 2005; Maloni and Brown, 2006), and fast food companies such as McDonalds (Schröder and McEachern, 2005; Maloni and Brown, 2006; Valax, 2012). On the contrary of those studies, this study focused on analyzing the social responsibility practices of municipalities as one of the types of local governments. The purpose of this 
study was to analyze the social responsibility practices of various municipalities in Izmir and to represent the social responsibility practices of different municipalities. This research contributes to the literature in terms of representing the social responsibility practices which were implemented by the municipalities of Izmir City.

\section{Research Methodology}

In this study, qualitative research was conducted to investigate the municipalities' social responsibility practices in deeply and to show the different municipalities' practices on social responsibility. Qualitative research is based upon analyzing concrete cases from people's expressions and activities in their local conditions (Flick, 2009: 21) and producing information about people's lifestyles, history, attitudes, organizational structures and social change (Strauss and Corbin, 1990). Ozdemir (2010: 326) stated that qualitative research is defined as a method of producing information in order to explore the depths of the society and to solve the secrets of human life. This research is mainly based upon exploratory, inductive and qualitative methods.

Within the scope of the aim of the research, a preliminary study was conducted as a first stage. In this preliminary study, all urban and rural municipalities in Izmir called via telephone and asked firstly whether they have implemented any social responsibility activities or not and secondly names of the directorates that implement social responsibility activities were asked. As a result of this telephone interviewing, it was found out that four rural municipalities did not implement any social responsibility practices. Therefore, these four municipalities were excluded from the research. The municipalities and the names of the directorates were shown below in Table 2.

Table 2. Municipalities and their directorates that implement social responsibility

\begin{tabular}{|c|c|}
\hline Municipalities & Directorate of .................. \\
\hline Karabağlar & Social Aid Affairs, Culture \\
\hline Buca & Social Aid Affairs, Culture, Agriculture \\
\hline Bornova & $\begin{array}{l}\text { Social Aid Affairs, Veterinary Affairs, Parks and Gardens, Health Affairs, Culture and } \\
\text { Social Affairs }\end{array}$ \\
\hline Konak & Social Aid Affairs, Public Relations, Culture \\
\hline Karşıyaka & $\begin{array}{l}\text { Social Aid Affairs, Culture, Protocol, Veterinary Affairs, Parks and Gardens, Health } \\
\text { Affairs, Strategy Development, Sports }\end{array}$ \\
\hline Bayrakl1 & Social Aid Affairs, Veterinary Affairs, Culture, Parks and Gardens, Private Secretary \\
\hline Çiğli & Culture, Public Relations \\
\hline Gaziemir & Social Aid Affairs \\
\hline Balçova & Social Aid Affairs \\
\hline Narlidere & Culture and Social Affairs, Center for Disabled People, Women Counseling Center \\
\hline Güzelbahçe & Culture and Social Affairs, Health Affairs, Private Secretary \\
\hline Torbalı & Social Aid Affairs \\
\hline Menemen & Social Aid Affairs \\
\hline Ödemiş & Social Aid Affairs \\
\hline Bergama & Culture and Social Affairs, Social Aid Affairs, Strategy Development \\
\hline Kemalpaşa & Culture \\
\hline Aliağa & Social-Cultural and Administrative Affairs \\
\hline Tire & Culture and Social Affairs \\
\hline Menderes & Culture and Social Affairs \\
\hline Urla & - \\
\hline Kiraz & - \\
\hline Dikili & Culture and Social Affairs, Social Aid Affairs, Technical Works, Health Affairs \\
\hline Bayındır & Culture and Social Affairs, Veterinary Affairs, Parks and Gardens \\
\hline Çeşme & Culture, Social Assistance \\
\hline Seferihisar & Culture and Social Affairs, Veterinary Affairs, Environment and Audit \\
\hline Selçuk & Social Affairs, Culture, Veterinary Affairs, Environment and Health, Parks and Gardens \\
\hline Foça & Culture and Art Affairs \\
\hline Kinık & Cultural and Social Activities, Parks and Gardens \\
\hline Beydağ & - \\
\hline Karaburun & - \\
\hline
\end{tabular}


After getting these results, the websites of municipalities were scanned in order to understand the scope of municipalities. It was seen that municipalities generally perform their mandatory and discretionary duties, and announced them on their websites. Except Bayraklı Municipality, any municipalities did not mention any activities related to social responsibility practices in their websites. Bayraklı Municipality has a specific page in its website about social responsibility practices. They opened youth centers which give free courses to students, dormitory for girls. They also deliver books to the houses of disabled people. Some of the activities that were organized by the municipalities in Izmir City were explained below.

Aliağa Municipality opened children shelters, art house, and a social market which creates a free market for people who bring and donate their second hand goods. Bayındır Municipality gives importance to environmental issues. Bergama Municipality opened a public soup-kitchen, free hobby courses and women support center. Çeşme Municipality organized social aids and free summer courses for developing theatre skills. Dikili Municipality has activities regarding youth center and planting trees. Foça Municipality opened free hobby courses. Kemalpasa Municipality opened free hobby courses and a support desk for European Union projects. Kınık and Menderes Municipalities opened a youth center. Menemen Municipality provided using women labor in contract manufacturing. They also supported university students with a monetary aid. Ödemiş Municipality opened nursing houses, new cafes which are suitable for using of disabled people. Seferihisar Municipality supported arts and sports activities. Tire Municipality opened free hobby courses and supported recreation of historical places. Torbal1 Municipality opened free arts and culture courses.

Balçova Municipality opened city houses which contain free courses such as chess, drama, jewelry design, and wood painting. It also built sport schools for young people and gave consultancy about health issues. Bornova Municipality opened free courses for young people under the name of "Belgem Training Center". They also opened a Science Center which promotes children to get interested in science. They delivered Dostcard which enables price cutting in university students' shopping. Buca Municipality opened culture and sports centers for young people. Çiğli Municipality opened a kinder garden, gave free courses and consultancy for entrepreneurs, gave free hobby courses, and started a campaign to provide free house goods for university students. Gaziemir Municipality opened free hobby courses for women and sports courses for young people, and supported unemployed people. Güzelbahçe Municipality opened city houses for free hobby courses and sports center for young people, and collected wasted oil. Karabağlar Municipality supplied monetary aid to the soldier family. Karşıyaka Municipality had many projects on youth centers, nursery services, library for disabled people, women support center, recycling, forestry, and chamber music. Konak Municipality is very active on the projects regarding children, music, arts and sports.

These activities got through scanning municipalities' websites show that municipalities' some duties may be evaluated in terms of social responsibility practices. Because of analyzing social responsibility practices via website analysis would be insufficient for the research reliability and validity, it was decided to conduct face-to-face interviewing with municipal officials and ask them social responsibility practices of municipalities to investigate the social responsibility activities of municipalities deeply. After taking the data from telephone interviewing and scanning websites the main research was conducted with faceto-face interviewing with municipal officials.

For the validity of the research, multiple and different sources of information were used in this study. Triangulation shows more detailed information of the situation and involves cross-checking the data from multiple resources (Vidovich, 2003: 78). For this reason, firstly telephone interviews were conducted to analyze the social responsibility practices of various municipalities, and then websites of the municipalities were scanned. Lastly, the main research was conducted via semi-structure interviewing which was explained broadly below.

\subsection{Sampling Technique}

In quantitative research, probability sampling depending on random and statistically representative sample that enables a generalization from the sample to a larger population (Patton, 1990: 169) and nonprobability (convenience) sampling are preferred, however qualitative research ignores these sampling techniques and reveals purposeful sampling (Maxwell, 2008). The power of purposeful sampling lies in selecting information-rich cases which provide a great deal about issues of central importance to the purpose of the research (Patton, 1990: 169). Since qualitative research does not search about quantify data, qualitative sampling does not aim to identify a statistically representative set of respondents, hence analyzing the results in frequencies may be misleading (Pope et al., 2000). In general, purposeful sampling techniques aim to collect detailed information about people or events that form the subject of 
the research.

In this study, maximum variation sampling technique as one of the purposeful sampling techniques was used to be able to get profound information about municipalities' social responsibility practices and to show the diversities between them. Maximum variation sampling, which is one of the purposeful sampling methods, describes the central themes (principal outcomes) and looks for profound information (Patton, 1990). In maximum variation sampling method, the main aim is to show the similarities and differences among different variations, but not to generalize the findings to all people. For example, a qualitative researcher searching about primary schools may choose the sample from the schools in the city center and rural area to show the differences and similarities between these two different segments of the city, but not to generalize these similarities and differences (Yildirim and Simsek, 2013).

Izmir city has thirty districts which include eleven urban districts and nineteen rural districts (Turkstat, 2014). Since the main purpose of the study was to analyze and show the different social responsibility practices of municipalities, two municipalities from urban districts, Karabaglar and Bornova, and two municipalities from rural districts, Kemalpasa and Seferihisar, were selected for qualitative research by using maximum variation sampling technique.

Descriptive statistics were gained from Turkstat Address Based Population Registration System (Turkstat, 2014). According to this data, Izmir city's total population is 4.113.072. With respect to this population statistics, Karabaglar Municipality (Population $_{\text {urban }+ \text { rural }}=473.741$, Population $_{\text {women }}=239.740$, Population $\left._{\text {men }}=234.001\right)$ is the biggest urban district, and Bornova Municipality (Population $_{\text {urban+rural }}=431.149$, Population $_{\text {women }}=215.253$, Population $\left.{ }_{\text {men }}=215.896\right)$ is the third biggest urban district of total eleven urban districts whereas Kemalpasa Municipality (Population $_{\text {urban+rural }}=99.626$, Population $_{\text {women }}=49.074$, Population $\left.{ }_{\text {men }}=50.552\right)$ is the fifth biggest rural district, and Seferihisar Municipality (Population ${\text { urban+rural: 35.960; } \text { Population }_{\text {women }}=17.326 \text {, Population }}_{\text {men }}=18.634$ ) is the fourteenth rural districts of total nineteen rural districts.

\subsection{Data Collection Method}

The mostly known techniques of qualitative research are: participant and non-participant observation, interviewing, group interviewing (focus group study), and collection of documentary materials (Dey, 2003). Interview technique, which is the mostly used data collection method and crucial for social scientific research (Briggs, 1986), includes interviewing with people who are related to research subject in order to gain a profound information regarding a particular purpose (Ozdemir, 2010: 328). Since the main aim in this study is to gather profound information about municipalities' social responsibility activities, semi-structured interviewing was implemented in this study. To be able to reach profound and well-designed information about municipalities' social responsibility practices, one municipal official from each municipality who is responsible for managing, organizing, and implementing the social responsibility activities in the districts was chosen for the semi-structured interviewing.

Interview techniques can be classified in three ways: structured, semi-structured, and in-depth interviewing (Britten, 1995: 251). Structured interviewing contains a structured questionnaire which should be followed by an interviewer strictly in a standardized manner. Since structured interviewing eliminates the negative interviewer effect (subjectivity) on research by asking the same questions to all interviewees in a systematic manner, it enables easy analysis and comparison of data (Yildirim and Simsek, 2013: 151). Semi-structured interviewing consists of standardized open-ended questions which define the issue to be explored. In semi-structured interviews, interviewee answers the questions without any restrictions such as time limitation, limitation the length of the contents of the answers, limitation the width of the contents of the answers (Batu et al., 2004). In-depth interviewing in which questions would be shaped according to what interviewee said is less structured than semi-structured interviewing and provides greater detailed information. It is advised not to be used by inexperienced researchers since it is open for negative interviewer effect (Yildirim and Simsek, 2013: 150).

Four municipal officials working for the social responsibility projects in the municipalities were called and appointments were retrieved. "Interview Form of Examining Municipal Social Responsibility Activities" which was used during the semi-structured interviewing process was prepared as standardized open-ended questions. Interviewees were not limited when answering the questions.

\subsection{Data Analysis}

Qualitative data provides descriptive elements and factual conditions regarding the research subject, so it should have detailed information about the research subject (Yildirim and Simsek, 2013: 147). Qualitative data analysis includes categorizing (such as coding and thematic analysis), connecting (such as narrative analysis and individual case studies), and memos and displays (Maxwell, 2008: 236). Miles and 
Huberman (2002: 396) clarified that mode of qualitative data analysis involves data reduction, data display, and preliminary and verified conclusion. Within this concept respectively, data was transcribed from the recorder, framework (coding plan) was generated and coding was implemented to reduce the data, some of the findings were shown in a table in order to display the data, and final outcome as a drawing conclusion was constituted. In this study, qualitative data analysis contains direct quotations to emphasize and reflect interviewees' opinions dramatically. In this type of data analysis, the main aim is to show the summarized and interpreted findings gaining from the research (Yildirim and Simsek, 2013: 256; Ozdemir, 2010: 336). To provide the reliability of the research, the whole data were analyzed by the five researchers separately, and then the findings were interpreted.

\section{Findings}

This study has revealed the findings regarding municipalities' social responsibility activities. It was not possible to generalize these findings to all municipalities in Izmir. This study has just shown two urban and two rural municipalities' social responsibility practices. The findings about four municipalities' social responsibility (SR) practices conducted so far were shown below.

The first question that was asked to municipal officials was about the duration of SR practices. The official from Seferihisar Municipality answered that "Seferihisar Municipality has been conducting SR activities for nearly 15 years". It means Seferihisar Municipality began SR practices in 2000. The official from Bornova Municipality said that "Bornova Municipality has been conducting SR activities regularly since 2012 under the directorate". Kemalpasa Municipality has maintained social responsibility activities actively since 2004. The official from Karabaglar Municipality said that "Karabaglar Municipality was founded in 2009 and after the foundation we started to plan social responsibility projects".

Municipalities' main purposes in conducting SR activities were asked to the officials. The official from Seferihisar Municipality answered that "to integrate different and disadvantaged groups to the society and make financial aid". The official from Bornova Municipality emphasized to make financial aid that was gathered from municipality's own financial budget and donations from institutions, foundations, public corporations, and citizens. Also the official from Bornova Municipality added that "the aim of municipalities is to follow the innovations and provide services by implementing these innovations which are possible for applying". The official from Kemalpasa Municipality said that "SR practices are conducted by the municipality because of labor force and income level in the district are below the standard". The official from Karabaglar Municipality answered that "the purpose is to help the vulnerable groups". "The vulnerable group" is not defined well by the official, however it was thought that it was used for low income and disadvantaged people.

It was asked to the officials in which area they have been implementing SR activities. The official from Seferihisar Municipality said that "we have been implementing SR activities in the area of health, women, environment, social, education". The official from Bornova Municipality has been conducting SR practices regarding animals, environment, health, social aid, culture. Kemalpasa Municipality has been implementing SR practices regarding environment, culture, and social affairs. "Karabaglar Municipality has been conducting in the area of health, education, and consultation".

It was asked to the officials to give more detail information regarding the mostly implemented practices. Seferihisar Municipality has been implementing social responsibility activities mostly in Sefericard Project which is a type of social aid practices whereas Bornova Municiality has been implementing social responsibility activities mostly in health, social aid, and culture. Moreover, the official from Bornova Municipality stated that "the municipality is particularly interested in the citizens who need of assistance in the field of education and food". Kemalpasa Municipality gives more importance in these areas: health, sports, food, and education. The official from Karabaglar Municipality answered that "We do not want to give importance to one category. We are trying to be homogeneous".

The officials answered the question regarding the directorates that implement SR practices. In Seferihisar Municipality, social responsibility activities have been implementing under the directorates such as the Directorate of Social Aid Affairs (new directorate comprised of merging the Directorate of Culture and Social Affairs, and the Directorate of Women Consultation), the Directorate of International Affairs, the Directorate of Projects, the Directorate of Environment, the Directorate of Parks and Gardens. The official from Seferihisar Municipality stated that "each directorate participates in social responsibility activities from time to time". "Bornova Municipality has been conducting SR activities under the Directorate of Veterinary Affairs, the Directorate of Parks and Gardens, the Directorate of Health Affairs, the Directorate of Social Aid Affairs, the Directorate of Culture and Social Affairs". In Kemalpasa Municipality, the Directorate of Culture and Social Affairs, the Directorate of Parks and Gardens, the Directorate of Environment and Protection have been fulfilling its social responsibility 
Yarimoglu, E.K., Hacioglu, F., Gencturk, S., Kamali Celik, Y.Sayginer, C./Journal of Yasar University, 2015, 10 Special Issue , 75-92

activities. In Karabaglar Municipality, "the activities are conducted by The Directorate of Social Aid Affairs. We are working together with the other departments. For example, the firewood project is conducted with the Directorate of Parks and Gardens, and the nursing projects are conducted with the Directorate of Health".

The official from Seferihisar Municipality represented the numbers of people who were served within Sefericard. "Sefericard Project as a social aid project started in Seferihisar Municipality in 2012. More than 5.000 Sefericards have been delivered until today. Sefericard is classified into three parts: First type is for citizens living in Seferihisar and costs $10 \mathrm{TL}$ for each person. Its benefits are free usage of Seferihisar's facilities such as free entry to beach, free bike renting, and free car park. Second type of Sefericard is for students. There is no card fee. The students having Sefericard are given stationary aid up to $50 \mathrm{TL}$. The last type of Sefericard is for financial aid. If an income per person is lower than half of the minimum wage in a family, this person can get financial help from the Municipality". The number of people who use Sefericard actively was shown in Table 1 below.

The officials from Bornova, Kemalpasa, and Karabaglar Municipalities provided the numbers of people who were participated in social responsibility practices. The official from the Karabaglar Municipality stated that "This year we started a new project called Food Card for social support. The number of people who applied to take the card is nearly 500. Also, we have Food House, everyday nearly 250 people eats from our house. Between 1 July and 31 December 2014, 1.524 houses were investigated and 2.170 food boxes were delivered. (In the first three months of 2015, 423 houses were investigated). In 2014, condolence foods were served to 6.165 people in 6 months. 20 people has been taking nursing service. In 2014, 331 families used laundry houses in 6 months. 368 people in 2014, and 123 people in 2015 took firewood aid. In 2014, total amount paid to the families of the soldiers was 751.185.000 TL. There are 4.951 registered disabled people in our database and until today we helped 7.579 disabled people". The number of people that have been served by SR practices in the municipalities was shown in Table 3 below.

Table 3. The number of people who participated in SR practices

\begin{tabular}{|l|l|l|l|}
\hline Seferihisar & Bornova & Kemalpasa & Karabaglar \\
\hline $\begin{array}{l}\text { Citizen } \\
\text { Sefericard: } 506\end{array}$ & Food aid: 9.583 & Food aid: 12.000 & $\begin{array}{l}\text { Food aid: 8.335 (except the } \\
\text { data of Food Card and Food } \\
\text { House) }\end{array}$ \\
\hline $\begin{array}{l}\text { Student } \\
\text { Sefericard: } 3.653\end{array}$ & $\begin{array}{l}\text { Trip aid for } \\
\text { housewives: } 10.500\end{array}$ & $\begin{array}{l}\text { Book aid for students: } \\
4.000\end{array}$ & Nursing: 20 \\
\hline $\begin{array}{l}\text { Financial Aid } \\
\text { Sefericard: } 1.309\end{array}$ & $\begin{array}{l}\text { Stationary aid for } \\
\text { students: } 1.500\end{array}$ & $\begin{array}{l}\text { University Entry Exam } \\
\text { Preparation Courses for } \\
\text { students: } 1.500\end{array}$ & Laundry: 331 families \\
\hline & $\begin{array}{l}\text { Stationary aid for } \\
\text { students: } 3.700\end{array}$ & Firewood aid: 491 \\
& students: 5.000 & & $\begin{array}{l}\text { Soldier family aid: } \\
751.185 .000 \text { TL }\end{array}$ \\
\hline & & & $\begin{array}{l}\text { Aid for disabled people: } \\
7.579\end{array}$ \\
\hline
\end{tabular}

All municipalities' SR Practices that have been implemented until today were shown below. To describe the practices that have been implementing until today, tables were used in order to be easier to read.

Table 4. Seferihisar Municipality's SR Practices

\begin{tabular}{|l|l|l|l|l|l|l|}
\hline Social Support & \multicolumn{1}{|c|}{ Health } & Education & Culture & Environment & Animal & $\begin{array}{l}\text { Women } \\
\text { Consultation }\end{array}$ \\
\hline $\begin{array}{l}\text { Welcome Baby } \\
\text { Project }\end{array}$ & $\begin{array}{l}\text { Carrying } \\
\text { disabled people } \\
\text { to hospitals }\end{array}$ & $\begin{array}{l}\text { Free } \\
\text { preliminary } \\
\text { courses }\end{array}$ & $\begin{array}{l}\text { The chorus } \\
\text { forming by } \\
\text { disabled } \\
\text { people }\end{array}$ & $\begin{array}{l}\text { Local seeds } \\
\text { were grown } \\
\text { and delivered } \\
\text { for free }\end{array}$ & $\begin{array}{l}\text { Delivering } \\
\text { free food } \\
\text { for } \\
\text { animals }\end{array}$ & $\begin{array}{l}\text { Women } \\
\text { Counseling } \\
\text { Center }\end{array}$ \\
\hline $\begin{array}{l}\text { Delivering milk } \\
\text { and juice }\end{array}$ & $\begin{array}{l}\text { Paying hospital } \\
\text { expenses to the } \\
\text { people having } \\
\text { Sefericard }\end{array}$ & $\begin{array}{l}\text { Children } \\
\text { participated } \\
\text { in } \\
70 \text { courses }\end{array}$ & $\begin{array}{l}\text { Students } \\
\text { were sent to } \\
\text { the activities } \\
\text { in foreign }\end{array}$ & $\begin{array}{l}21 \text { new } \\
\text { gardens were } \\
\text { built on } \\
53.000 \mathrm{~m}^{2}\end{array}$ & & $\begin{array}{l}\text { Vocational } \\
\text { development } \\
\text { courses }\end{array}$ \\
\hline
\end{tabular}




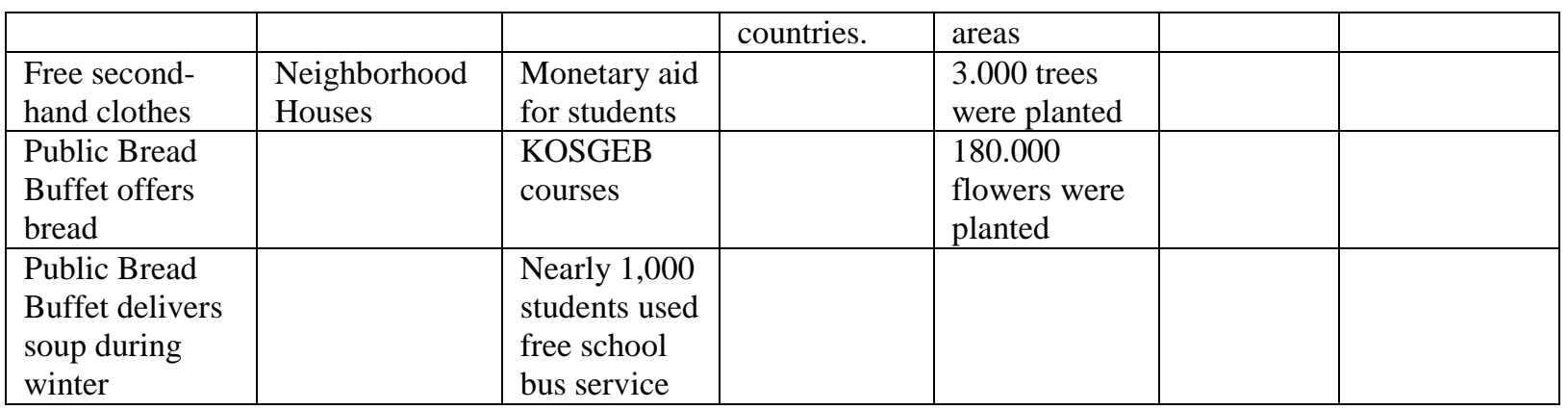

Some of the projects of Seferihisar Municipality: Welcome Baby Package and free baby food were delivered to the newborn babies' families within Welcome Baby Project. 200,000 boxes of milk and 100,000 bottles of mandarin juice were delivered to the kids. In the women Counseling Center, psychological and legal support were given to women. Local seeds were grown, protected, and distributed for free in Can Yücel Seed Center with the help of the Directorate of Parks and Gardens. Free animal food was delivered in the Animal Rights Day with the help of the Directorate of Environment. More than 2,000 students have taken free courses to prepare the university entrance exams. Almost 2,000 children have taken 70 different courses in the Child and Youth Center. People could take free second-hand clothes from the Clothes Donation Shop where the other people have donated their old clothes. In the Neighborhood Houses, mothers were able to leave their children to the playground, wash their clothes, and cook. In terms of monetary aids in education, a student who wins bachelor degree was given $500 \mathrm{TL}$ as a monetary aid, and a student who wins vocational school was given $250 \mathrm{TL}$ as a monetary aid. The Directorate of International Affairs and the Directorate of Projects arrange KOSGEB (Republic of Turkey Small and Medium Enterprises Development Organization) courses and also send students to the activities in foreign countries. Besides these practices, the official added that "transportation in Seferihisar is free for all students".

Table 5. Bornova Municipality's SR Practices

\begin{tabular}{|l|l|l|l|l|l|}
\hline Social Support & Health & Education & Culture & Environment & Animal \\
\hline $\begin{array}{l}\text { Disaster } \\
\text { assistance }\end{array}$ & $\begin{array}{l}\text { Birth control } \\
\text { methods }\end{array}$ & Stationery aid & $\begin{array}{l}\text { Yesilova Hill } \\
\text { Town was } \\
\text { taught to } \\
\text { students }\end{array}$ & $\begin{array}{l}\text { Donation of } \\
\text { firewoods }\end{array}$ & $\begin{array}{l}\text { Protecting } \\
\text { stray cats and } \\
\text { dogs }\end{array}$ \\
\hline $\begin{array}{l}\text { Soldier family } \\
\text { aid }\end{array}$ & Prenatal care & $\begin{array}{l}\text { Monetary aid for } \\
\text { primary and } \\
\text { secondary school } \\
\text { students }\end{array}$ & $\begin{array}{l}\text { Travel } \\
\text { opportunities }\end{array}$ & & $\begin{array}{l}\text { Placement of } \\
\text { stray cats and } \\
\text { dogs to the } \\
\text { shelters }\end{array}$ \\
\hline $\begin{array}{l}\text { Non-monetary } \\
\text { and monetary } \\
\text { aid for disabled } \\
\text { people }\end{array}$ & $\begin{array}{l}\text { Health } \\
\text { treatment and } \\
\text { medicines } \\
\text { were given to } \\
\text { citizens }\end{array}$ & $\begin{array}{l}\text { Daily hot meals for } \\
\text { students }\end{array}$ & & $\begin{array}{l}\text { Food aid for } \\
\text { animals }\end{array}$ \\
\hline Food aids & & $\begin{array}{l}\text { Hobby and skill } \\
\text { development } \\
\text { trainings for adults } \\
\text { and children }\end{array}$ & & & $\begin{array}{l}\text { Health } \\
\text { controls of } \\
\text { animals }\end{array}$ \\
\hline $\begin{array}{l}\text { Free second- } \\
\text { hand clothes }\end{array}$ & & $\begin{array}{l}\text { Swimming lessons } \\
\text { were given for } \\
\text { disabled people }\end{array}$ & & & $\begin{array}{l}\text { Neutering of } \\
\text { animals }\end{array}$ \\
\hline Laundry service & & & & & \\
\hline
\end{tabular}

The Directorate of Social Aid Affairs has implemented practices such as: Disaster assistance is provided in case of natural disasters such as earthquake, flood, and fire. Monetary aid is provided to the low income soldier family whose son completes the first 45 days of his military duty. Travel facilities are provided for these groups: low income people, successful students, elders, disabled people, and housewives. Food aids are provided temporary or permanently for low income families and disabled 
people. People can take free second-hand clothes from the Bank of Clothing where the other people have donated their old clothes. Stationery materials such as notebooks, books, student uniforms, and bags were given the needy students. The Directorate of Culture and Social Affairs organized facilities about Yesilova Hill Town. Chronological and historical development of Yesilova Hill Town was taught to elementary school students. Birth control methods and prenatal care was given by the Directorate of Health Affairs. Tree branches separating from the main body of the tree by pruning were transformed to firewoods and then these firewoods were donated to the citizens by the Directorate of Parks and Garden. On behalf of the Directorate of Veterinary Services, the stray cats and dogs were protected, placed to the shelters, provided food and health control, and neutered.

Table 6. Kemalpasa Municipality's SR Practices

\begin{tabular}{|c|c|c|c|c|c|}
\hline Social Support & Health & Education & Culture & Environment & Animal \\
\hline $\begin{array}{l}\text { Soldier family } \\
\text { aid }\end{array}$ & $\begin{array}{l}\text { Health care } \\
\text { at home }\end{array}$ & $\begin{array}{l}\text { Free courses for } \\
\text { students }\end{array}$ & $\begin{array}{l}\text { Exchange } \\
\text { programs }\end{array}$ & $\begin{array}{l}\text { Donation of } \\
\text { firewoods }\end{array}$ & $\begin{array}{l}\text { Food aid for } \\
\text { pets }\end{array}$ \\
\hline Food aid & Nursing & Music courses & $\begin{array}{l}\text { "Each village } \\
\text { is a scene", } \\
\text { Project }\end{array}$ & & $\begin{array}{l}\text { Food aid for } \\
\text { stray cats and } \\
\text { dogs }\end{array}$ \\
\hline $\begin{array}{l}\text { Free second- } \\
\text { hand clothes and } \\
\text { white goods }\end{array}$ & $\begin{array}{l}\text { Nursing for } \\
\text { disabled } \\
\text { people }\end{array}$ & $\begin{array}{l}\text { Courses for } \\
\text { Down's syndrome } \\
\text { children }\end{array}$ & City Theater & & $\begin{array}{l}\text { Temporal } \\
\text { Animal Care } \\
\text { Houses } \\
\end{array}$ \\
\hline $\begin{array}{l}\text { Welcome baby } \\
\text { package }\end{array}$ & $\begin{array}{l}\text { Ambulance } \\
\text { assistant }\end{array}$ & $\begin{array}{l}\text { Free hobby } \\
\text { courses }\end{array}$ & $\begin{array}{l}\text { Travel } \\
\text { opportunities }\end{array}$ & & \\
\hline $\begin{array}{l}\text { Cleaning service } \\
\text { for home }\end{array}$ & & $\begin{array}{l}\text { Swimming } \\
\text { courses }\end{array}$ & & & \\
\hline $\begin{array}{l}\text { Condolence } \\
\text { foods }\end{array}$ & & $\begin{array}{l}\text { Sports training } \\
\text { courses }\end{array}$ & & & \\
\hline Ramadan aid & & & & & \\
\hline
\end{tabular}

Monetary aid is provided to every young soldier and his family. Homeless and poor people are made food aid with specific foods. Baby bag and a gift (quarter gold) are given to newborn babies within Welcome Baby Package. Patients who are living alone, elderly or bedridden are provided home cleaning services. Hot meals are delivered to each house that has funeral. Travel facilities were supplied by arranging trips to Urfa and Mardin with professional guides for 21.000 women. During the month of Ramadan, free food aid is given as dinner for 2000 people. Health care at home, ambulance assistant, and nursing services are provided to the elderly homeless or unable to walk patients. Hobby courses about guitar, diction, theater, drama, folk music, classical music, folk dances are given, also painting and music courses are given to Down's syndrome children. There are 3 different swimming programs for children, disabled people, and citizens. Sports training courses such as gymnastics, aerobics, tennis, basketball, volleyball, football, and handball courses are offered. Exchange program for both teachers and students. Three students and two teachers from Hungary, Poland, Cyprus, Croatia, Greece, and Italy came to the district to organize street games. "Each village is a scene" Project organizes a theater show every year on the 23rd of April, which is a day of children's bayram in Turkey. The unused municipal truck is used for the theater and free show is demonstrated in village schools' gardens for the students who cannot go to the theater. Kemalpasa City Theater organizes free theater shows to provide free art activities on every Friday and Saturday for all citizens. Tree branches were transformed to firewoods which were donated to the citizens. Food aid is provided to the families who have the pets by registering the pets in the district. Besides this, food aid such as bread and water on the street for stray cats and dogs are also provided. Temporal Animal Care Houses for the sterilization of stray animals, immunization, and labeling were provided.

Table 7. Karabaglar Municipality's SR Practices

\begin{tabular}{|l|l|l|l|l|}
\hline Social Support & Health & Education & Culture & Environment \\
\hline $\begin{array}{l}\text { Card for low } \\
\text { income people }\end{array}$ & $\begin{array}{l}\text { Consulting } \\
\text { centers }\end{array}$ & $\begin{array}{l}\text { Free vocational } \\
\text { courses }\end{array}$ & $\begin{array}{l}\text { Travel } \\
\text { opportunities }\end{array}$ & $\begin{array}{l}\text { Donation of } \\
\text { firewoods }\end{array}$ \\
\hline Condolence foods & $\begin{array}{l}\text { Medical support } \\
\text { to ill and old } \\
\text { people }\end{array}$ & $\begin{array}{l}16.000 \text { pencils } \\
\text { were delivered } \\
\text { to the students. }\end{array}$ & & \\
\end{tabular}




\begin{tabular}{|l|l|l|l|l|}
\hline Food Houses & & $\begin{array}{l}4.300 \text { notebooks } \\
\text { were delivered } \\
\text { to the teachers. }\end{array}$ & & \\
\hline Soldier family aid & & & & \\
\hline Ramadan aid & & & & \\
\hline
\end{tabular}

The official from Karabaglar Municipalty gave the information about SR practices and some of them was like that: "At the beginning of 2014-2015 educational year, total 16.000 pencil sets were delivered to the thirty-eight primary schools in the district. To celebrate Teacher's Day on 24th November 2014, 4.300 notebooks were delivered to the teachers in ninety-seven schools. 538 women and children were taken to trips (Yassicaada, Gümüldür, museums and theaters). We helped to soldier's family. We pay 155 TL to soldier's wife and if they have a child we pay additional 65 TL. During Ramadan month, each day food was given to nearly 800 people for dinner".

Future intentions regarding SR practices were diversified in each municipality. The official from Seferihisar Municipality said that "The Directorate of Social Aid Affairs which is the new directorate of the Municipality coordinates the new SR activities. However, for now there is no new projects planned". On the contrary of Seferihisar Municipality, Bornova Municipality is planning a new project on developing vocational courses for women. Kemalpasa Municipality is developing projects regarding the trips and education by focusing on educational and exchange programs. Karabaglar Municipality is planning to establish the Women Consulting Center, Consultation Center for Elder People, Center for Kids and Teens, and women friendly parks which are enable for walking with high heels, entering with stroller and having baby care rooms.

SR practices are perceived as "a part of the municipality" and "a permanent activity" by the all municipalities. SR practices should be a developing process and municipalities should provide SR activities for contributing to both citizens and local government. Seferihisar, Kemalpasa, and Karabaglar Municipalities did not take any payment for participating in the SR practices that have been organized until today. However, the official from Bornova Municipality said that "Bornova Municipality took a small amount of payment in some cases".

\section{Conclusion}

There are thirty municipalities in Izmir City and a preliminary study which was conducted through telephone interviewing as a first stage of the research showed that twenty six municipalities have been implementing SR practices in Izmir City. It was found out that four rural municipalities did not implement any social responsibility practices. These municipalities which are rural municipalities are: Urla, Kiraz, Beydağ, Karaburun Municipalities. It can be suggested to these municipalities to conduct SR practices because of lower level of socio and economic development. Especially, rural districts should conduct or increase the level of SR practices.

After telephone interviewing, the websites of municipalities were scanned to understand the scope of SR practices. However, there was no specific information or SR button in the webpages. It was seen that municipalities generally perform their mandatory and discretionary duties, and announced them on their websites. The websites did not contain any information about SR practices. There was only one municipality among thirty municipalities which designs a page for SR practices and announces its SR practices. It was Bayrakli Municipality that mentioned SR practices in its website. It is highly advised to the municipalities use online communication channels actively, and design a separate webpages to share SR practices with the citizens.

After doing a preliminary study, the main research was conducted via face-to-face semi-structured interviewing in order to get profound and rich information from the municipal officials. According to the findings about duration of SR practices, the first municipality that begins to implement SR practices is Seferihisar Municipality. SR practices started in the municipalities after 2000s and the sequences according to the starting dates respectively are as follows Seferihisar, Kemalpasa, Karabaglar, and Bornova. It showed that rural municipalities began SR practices earlier. It may be because of rural districts have lower income and education level than urban districts. So they need much more SR practices for socio and economic development. Rural municipalities should be also supported by governmental organizations.

Municipalities focus on financial aids and helping people to increase welfare and interest of society. It can be said that both monetary and non-monetary helpings are implemented by the municipalities. 
Generally, they implement SR practices regarding social support, health, education, culture, environment, and animals. The Directorate of Social Aid Affairs is the main directorate for implementing SR practices in all municipalities. Seferihisar Municipality has established this directorate recently, Bornova Municipality also established a new directorate as the Directorate of Culture and Social Affairs in addition to the Directorate of Social Aid Affairs. Kemalpasa Municipality established just only the Directorate of Culture and Social Affairs whereas Karabaglar Municipality just has the Directorate of Social Aid Affairs.

Seferihisar Municipality focused on SR practices via Sefericard which is a social aid project. It served 5.468 people within this card. The officials from Bornova, Kemalpasa, and Karabaglar Municipalities provided the numbers of people who were participated in social responsibility practices. According to this data, respectively Bornova Municipality provided projects to 26.583 people, Kemalpasa Municipality provided projects to 21.200 people, Karabaglar Municipality provided projects to 16.756 people and soldier family aid.

Seferihisar Municipality focused on seven main areas such as social support, health, education, culture, environment, animal, and women consultation whereas the other municipalities focused on six main areas such as social support, health, education, culture, environment, and animal. Generally all municipalities have social support activities and these activities are conducted by the Directorate of Social Aid affairs.

All municipalities' SR Practices that have been implemented until today were explained in detail above. It can be said that the maximum diversification in SR practices are highly seen in Seferihisar Municipality in all four municipalities. Seferihisar Municipality's SR practices are focused on women consultation activities muchly, and KOSGEB courses to educate children and send them to foreign countries. Besides this, building gardens and planting flowers and trees which were implemented by the help of the Directorate of Parks and Gardens are popular activities in Seferihisar Municipality.

Bornova Municipality generally gives importance to university students. It may be because of Bornova district is a host of several universities and university students. Also it focused on cultural element as teaching the history of some cultural places. The other important SR practices in Bornova is its travel opportunities for especially women and students.

Kemalpasa Municipality's cultural practices are primary. It has an active City Theater, and conducts some different cultural projects such as exchange programs and theater projects. Moreover, hobby courses such as guitar, diction, theater, drama, folk music, classical music, folk dances, and painting, and sports courses such as swimming, gymnastics, aerobics, tennis, basketball, volleyball, football, and handball are highly interested in the district.

Karabaglar Municipality delivered some stationary equipment for celebrating new academic year or Teacher's day. The official from Karabaglar Municipality said that the SR practices and the management of these facilities have conducted in the same way with Bornova Municipality.

It can be said that SR practices that have been mostly conducted by the municipalities in Izmir are: food aids, soldier family aids, free second-hand clothes, free preliminary courses for students, free hobby and vocational courses, delivering free food for animals, monetary aid for students, firewoods donations, stationery aids for students, and disabled people aids such as carrying disabled people to hospitals, nonmonetary and monetary aid for disabled people, nursing for disabled people.

As further projects, municipalities are planning some projects such as Bornova Municipality is planning a new project on developing vocational courses for women, Kemalpasa Municipality is developing projects regarding the trips and education, Karabaglar Municipality is planning to establish the Women Consulting Center, Consultation Center for Elder People, Center for Kids and Teens, and women friendly parks. Municipalities are seen SR practices as a part of municipalities and permanent activities. They should be a developing process and they should contribute to the citizens.

The municipalities' SR practices should be increased and these practices should be compulsory activities of municipalities. Increasing of SR practices provides social welfare in a society. Izmir City has many various SR practices, however still they should be improved. Especially rural municipalities provides some SR practices for the citizens who are lack of social, economic, and technologic developments. Municipalities should separate their own duties and social responsibility projects from each other. Moreover, they should design a new SR projects webpage within their websites to communicate their citizens. Citizens should be educated regarding the participating in SR practices. 
Yarimoglu, E.K., Hacioglu, F., Gencturk, S., Kamali Celik, Y.Sayginer, C./Journal of Yasar University, 2015, 10 Special Issue , 75-92

\section{Limitations \& Further Research}

In this study, only four municipalities of Izmir City were analyzed in terms of social responsibility practices. The remaining municipalities also can be investigated from a detailed perspective, and a Social Responsibility Plan of Izmir City may be constituted. Moreover, data collection method of this study can be enhanced in further research. In this study, semi-structured interviews with municipal officials represented the SR practices from the point of view of municipalities. Besides the interview, a quantitative study and a survey can be applied to the citizens to learn their ideas about municipalities' SR practices to be able to get information from the point of view of citizens. 
Yarimoglu, E.K., Hacioglu, F., Gencturk, S., Kamali Celik, Y.Sayginer, C./Journal of Yasar University, 2015, 10 Special Issue , 75-92

\section{REFERENCES}

Akdogan, Y. (2002). Ulusal soruna yerel çözüm: Sosyal belediyecilik. Eminönü Bülteni, Istanbul.

Argenti, P. A. (2004). Collaborating with activists: How Starbucks works with NGOs. California Management Review, 47 (1), 91-116.

Batu, E. S., Kırcaali-İftar, G., \& Uzuner, Y. (2004). Özel gereksinimli öğrencilerin kaynaştırıldığı bir kız meslek lisesindeki öğretmenlerin kaynaştırmaya ilişkin görüş ve önerileri. Ankara Üniversitesi Eğitim Bilimleri Fakültesi Özel Eğitim Dergisi, 5 (2) 33-50.

Bowen, H. R. (1953). Social responsibilities of the businessman. New York: Harper \& Row.

Briggs, C. L. (1986). Learning How to Ask: A Sociolinguistic Appraisal of the Role of the Interview in Social Science Research. Cambridge University Press

Britten, N. (1995). Qualitative research: qualitative interviews in medical research. BMJ (British Medical Journal), 311(6999), 251-253.

Carroll, A. B. (1979). A three-dimensional conceptual model of corporate performance. Academy of management review, 4(4), 497-505.

Carroll, A. B. (1991). The pyramid of corporate social responsibility: toward the moral management of organizational stakeholders. Business horizons, 34(4), 39-48.

Carroll, A. B. \& A. K. Buchholtz. (2008). Business and Society: Ethics and Stakeholder Management. Mason, OH: South-Western College Publishing.

Chaudhary, N. K. (2009). Facilitators \& Bottlenecks of Corporate Social Responsibility. The Indian Journal of Industrial Relations, 44(3), 386-395.

Cicek, Ş.E. (2010). Türkiye'de belediyelerin sosyal hizmet ve sosyal yardım politikaları: Batı Akdeniz örneği, Süleyman Demirel Üniversitesi Sosyal Bilimler Enstitüsü Kamu Yönetimi Anabilim Dalı Doktora Tezi.

Crowther, D. \& Aras, G. (2009). Corporate Social Responsibility. http://bookboon.com/en/definingcorporate-social-responsibility-ebook [Accessed on 05.06.2014].

Dahlsrud, A. (2008). How corporate social responsibility is defined: An analysis of 37 definitions. Corporate Social Responsibility and Environmental Management, 15(1), 1-13.

Davey, K. (2011). Local Government in Critical Times: Policies for Crisis, Recovery and a Sustainable Future. Council of Europe: France.

Davis, K. (1960). Can business afford to ignore social responsibilities? California Management Review, 2(3), 70-76.

Dey, I. (2003). Qualitative data analysis: A user friendly guide for social scientists. Routledge.

Du, S., Bhattacharya, C. B., \& Sen, S. (2010). Maximizing business returns to corporate social responsibility (CSR): The role of CSR communication. International Journal of Management Reviews, 12(1), 8-19.

Es, M. (2007). Kentsel Yoksulluğun Azaltılmasında Sosyal Belediyeciliğin Rolü. Yerel Siyaset Dergisi, $1(3), 45-52$.

European Commission (EC) (2013). Communication from the Commission to the European Parliament and the Council Enlargement Strategies, Turkey Progress Report, [Accessed on 05.06.2014].

http://ec.europa.eu/enlargement/pdf/key_documents/2013/package/brochures/turkey_2013.pdf

Eweje, G. (2007). Multinational oil companies' CSR initiatives in Nigeria: The scepticism of stakeholders in host communities. Managerial Law, 49(5/6), 218-235.

Flick, U. (2009). An introduction to qualitative research. Sage.

Friedman, M. (1970). The Social Responsibility of Business is to Increase its Profits, The New York Times Magazine.

Frynas, J. G. (2005). The false developmental promise of Corporate Social Responsibility: evidence from multinational oil companies. International affairs, 81(3), 581-598.

General Directorate of Local Authorities (2011). Local Authorities in Turkey. http://www.migm.gov.tr/en/PDF/Municipalities.pdf [Accessed on 27.03.2015].

Gullupunar, H. (2010). Halkla İlişkilerde Sosyal Sorumluluk İlkesi: Kamu Kuruluşları Yaklaşımı Bakımından Konya Büyükşehir Belediyesi Uygulama Örnekleri. Gümüşhane Üniversitesi Sosyal Bilimler Elektronik Dergisi, 1(1), 31-54

Gunal, V. A. (2013). Merkezi Yönetim-Belediye İlişkileri'nde Antalya Büyükşehir Belediyesi Örneği. Uluslararası Alanya İşletme Fakültesi Dergisi,5(1).

Heal, G. (2005). Corporate social responsibility: An economic and financial framework. The Geneva papers on risk and insurance-Issues and practice, 30(3), 387-409. 
Yarimoglu, E.K., Hacioglu, F., Gencturk, S., Kamali Celik, Y.Sayginer, C./Journal of Yasar University, 2015, 10 Special Issue , 75-92

Karaman, Z. T. (2010). Democratic Gains in Public Administration at Local Level in Terms of CSR: Theory and Practice-Based Approaches at Izmir Metropolitan City, Turkey. In Professionals' Perspectives of Corporate Social Responsibility (pp. 319-344). Springer: Berlin Heidelberg.

Khan, H. U. Z., Halabi, A. K., \& Samy, M. (2009). Corporate social responsibility (CSR) reporting: a study of selected banking companies in Bangladesh. Social responsibility journal, 5(3), 344-357.

Kolk, A. (2005). Corporate Social Responsibility in the Coffee Sector: The Dynamics of MNC Responses and Code Development. European Management Journal, 23(2), 228-236.

Kotler, P. \& Lee, N. (2005). Corporate Social Responsibility: Doing the Most Good for Your Company and Your Cause, New Jersey: John Wiley \& Sons.

Law on Special Provincial Administration. (2005). No. 5302, Article 3, http://www.migm.gov.tr/en/Laws/Law5302_SpecialProvincialAdmin_2010-12-31_EN_rev01.pdf [Accessed on 27.03.2015].

Mahalli İdareler Genel Müdürlüğü (2014). 2013 yılı Mahalli İdareler Genel Faaliyet Raporu, Ankara,http://www.migm.gov.tr/Dokumanlar/2013_MAHALLI_IDARELER_GENEL_FAALIYE T_RAPORU.pdf [Accessed on 27.03.2015].

Maloni, M. J., \& Brown, M. E. (2006). Corporate social responsibility in the supply chain: an application in the food industry. Journal of business ethics, 68(1), 35-52.

Manne, H. \& Wallich, H. C. (1972). The modern corporation and social responsibility. Washington D.C.: American Enterprise Institute for Public Policy Research.

Maxwell, J. A. (2008). Designing a qualitative study. The SAGE Handbook of Applied Social Research Methods, SAGE, Los Angeles, 214-46.

Metropolitan Municipality Law. (2004). N. 5216.

http://www.migm.gov.tr/en/Laws/Law5216_MetropolitanMunicipalities_2010-12-31_EN_rev01.pdf [Accessed on 07.04.2015].

Miles, M. B. \& Huberman, A. M. (2002). The Qualitative Researcher's Companion. London: Sage.

Municipality Law. (2005). No. 5393, Article 3,

http://www.migm.gov.tr/en/Laws/Law5393_Municipality_2010-12-31_EN_rev01.pdf[Accessed

on 27.03.2015].

Narwal, M. (2007). CSR initiatives of Indian banking industry. Social Responsibility Journal, 3(4), 49-60.

Oates, W.E. (1972). Fiscal Federalism. Harcourt Brace: New York.

Ozdemir, M. (2010). Nitel veri analizi: Sosyal bilimlerde yöntembilim sorunsalı üzerine bir çalışma.

Eskişehir Osmangazi Üniversitesi Sosyal Bilimler Dergisi, 11(1), 323-343.

Ozdora-Aksak, E. (2015). An analysis of Turkey's telecommunications sector's social responsibility practices online. Public Relations Review.

Pasamehmetoglu, A., Ozdora-Aksak, E., \& Atakan-Duman, S. (2014), CSR as a Strategic Tool for Gaining Legitimacy: Mapping CSR Activities among Turkey's Largest Corporations. Proceedings of World Business and Social Science Research Conference, 14 - 16 April 2014, Hotel Crowne Plaza Republique, Paris, France, ISBN: 978-1-922069-47-4.

Patton, M. (1990). Qualitative evaluation and research methods (pp. 169-186). Beverly Hills, CA: Sage.

Perez, A. \& del Bosque, I. R. (2012). The role of CSR in the corporate identity of banking service providers. Journal of Business Ethics, 108(2), 145-166.

Poolthong, Y., \& Mandhachitara, R. (2009). Customer expectations of CSR, perceived service quality and brand effect in Thai retail banking. International Journal of Bank Marketing, 27(6), 408-427.

Pope, C., Ziebland, S., \& Mays, N. (2000). Qualitative research in health care: Analysing qualitative data. BMJ (British Medical Journal), 320(7227), 114-116.

Rani, G. \& Hooda, K. (2013). Corporate Social Responsibility: Review of Literature, International Journal of Social Science \& Interdisciplinary Research, 2 (6).

Schröder, M. J., \& McEachern, M. G. (2005). Fast foods and ethical consumer value: a focus on McDonald's and KFC. British Food Journal, 107(4), 212-224.

Sen, S., Bhattacharya, C. B., \& Korschun, D. (2006). The role of corporate social responsibility in strengthening multiple stakeholder relationships: A field experiment. Journal of the Academy of Marketing science, 34(2), 158-166.

Shah, A. \& Shah, S. (2006). The New Vision of Local Governance and the Evolving Roles of Local Governments. Local Governance in Developing Countries ed. A. Shah pp. 1-46. Washington D.C: World Bank.

Strauss, A. \& Corbin, J. M. (1990). Basics of qualitative research: Grounded theory procedures and techniques. Sage Publications, Inc.

The 1982 Constitution of the Republic of Turkey. Article 127. http://global.tbmm.gov.tr/docs/constitution_en.pdf [Accessed on 27.03.2015]. 
Yarimoglu, E.K., Hacioglu, F., Gencturk, S., Kamali Celik, Y.Sayginer, C./Journal of Yasar University, 2015, 10 Special Issue , 75-92

Toprak, Z. (2013a). Türkiye'nin İdari Yapılanmasında Yerel Yönetimler ve Felsefesi. Yerel Yönetimler Sempozyumu: Güncel Sorunlar Işı̆̆ında Türkiye'de Yerel Yönetimler, Yenimahalle Belediyesi, ODTÜ ve TUİÇ düzenlemesi, 21-22 Şubat, Ankara.

Toprak, Z. (2013b). Yerel yönetimler ve sivil toplum. Ortadoğu ve Sivil Toplum Diyalogu Çalıştayı (6-7 Nisan), Gaziantep.

Turkstat, 2014, http://rapory.tuik.gov.tr/19-03-2015-23:34:01-1835346098527271677226442178.html [Accessed on 19.03.2015].

Ucakturk, T., Ucakturk, A. \& Ozkan , M. (2009). Yerel Yönetimde Sosyal Sosyal Sorumluluk Bağlamında Sosyal Belediyecilik: Biga Belediyesi Örneği. VI. Uluslararası Sivil Toplum Kuruluşları Kongresi, Çanakkale.

UNDP (2010). Local Governance and Climate Change: A Discussion Note.http://www.unpei.org/sites/default/files/publications/LocalGovernanceAndClimateChangeDi scussionNote.pdf [Accessed on 07.04.2015].

Valax, M. (2012). Beyond McDonald's CSR in China: Corporation perspective and report from case studies on a damaged employment reputation. Asian Business \& Management, 11(3), 347-366.

Vidovich, L. (2003). Methodological framings for a policy trajectory study, in Qualitative educational research in action: Doing and reflecting, Eds: O'Donoghue, T., \& Punch, K., pp. 70-96, Routledge.

Vural, B. A. \& Oksuz, B. (2009). Kurumsal Web Siteleri Araciliğiyla Kurumsal Sosyal Sorumluluk Iletişimi: Türkiye'deki Gsm Operatörlerine Yönelik Bir Araştirma. Journal of Yaşar University, 4(13), 2043-2061.

Weber, M. (2008). The business case for corporate social responsibility: A company-level measurement approach for CSR. European Management Journal, 26(4), 247-261.

Yildirim, A. \& Simsek, H. (2013). Sosyal Bilimlerde Nitel Araştırma Yöntemleri. Seçkin Yayıncılık: Ankara.

Yuksel, F., Bozkurt, F. G. \& Guven, A. (2006). Yerel Yönetimlerde Etik Çerçevesinde Sosyal Sorumluluk Bilinci: Tokat Belediyesi Uygulaması, Siyasette ve Yönetimde Etik Sempozyumu. 